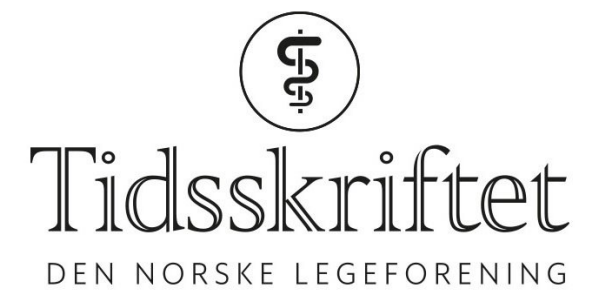

\title{
Aorta?
}

MEDISIN OG KUNST

\section{LARS BORGEN}

E-post: Lars.Borgen@vestreviken.no

Intervensjonsseksjonen

Avdeling for bildediagnostikk

Drammen sykehus

Vestre Viken

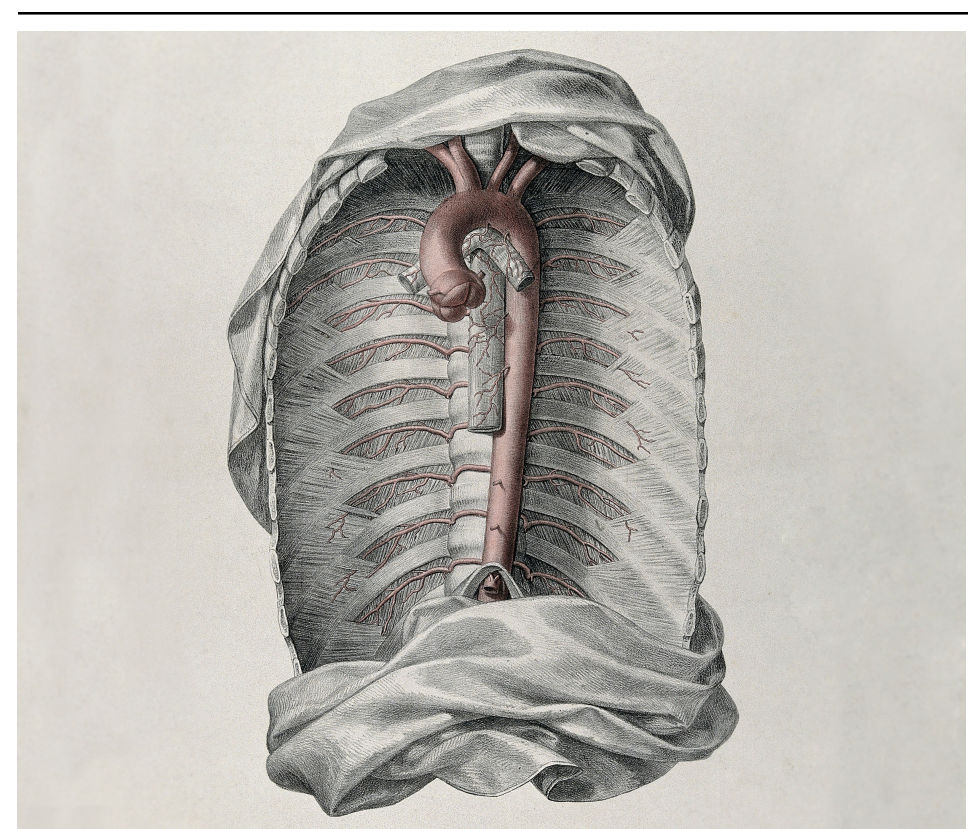

Litografi av Jakob Wilhelm Christian Roux fra 1822. Illustrasjon: Wellcome Library

Aortabuen gjør vendereis

Før stammen stuper ned

Gjennom mellomgulvet

På veien ut

Slukte du et rødt

Pulserende spørsmålstegn

Hektet fast i hjertet

Før alle delinger

Før alle fjerne gebet 
Så det første blodet gjør

På vei ut i det store kretsløp

Er å forme tegnet for åpenhet

Leukocyttenes uskyld

Erytrocyttenes begjær

Fanget i rytmen

Hvor-for, hvor-dan

Hvor-for, hvor-dan

Årene fingrer seg frem

Huden brenner et kapillærsvar

Som venene bringer hjem

Og i det lille kretsløp

Luftes svarene ut

Før en firkamret klokke

Tikker deg rastløst videre

Bare aorta står fast

Med dette ene:

Etter svale svar

Alltid et nytt kroppsvarmt

Hvor-for, hvor-dan

Hvor-for, hvor-dan

Publisert: 14. desember 2020. Tidsskr Nor Legeforen. DOI: 10.4045/tidsskr.20.0921

(C) Tidsskrift for Den norske legeforening 2020. Lastet ned fra tidsskriftet.no 